\title{
Garcinia dulcis Fruit Extract Induced Cytotoxicity and Apoptosis in HepG2 Liver Cancer Cell Line
}

\author{
Mohd Fadzelly Abu Bakar, ${ }^{1,2}$ Nor Ezani Ahmad, ${ }^{2}$ Monica Suleiman, \\ Asmah Rahmat, ${ }^{3}$ and Azizul Isha ${ }^{4}$ \\ ${ }^{1}$ Faculty of Science, Technology and Human Development, Universiti Tun Hussein Onn Malaysia (UTHM), Batu Pahat, \\ 86400 Parit Raja, Johor, Malaysia \\ ${ }^{2}$ Institute for Tropical Biology and Conservation, Universiti Malaysia Sabah, Jalan UMS, 88400 Kota Kinabalu, Sabah, Malaysia \\ ${ }^{3}$ Department of Nutrition and Dietetics, Faculty of Medicine and Health Sciences, Universiti Putra Malaysia (UPM), \\ 43400 Serdang, Selangor, Malaysia \\ ${ }^{4}$ Laboratory of Natural Products, Institute of Bioscience, Universiti Putra Malaysia (UPM), 43400 Serdang, Selangor, Malaysia
}

Correspondence should be addressed to Mohd Fadzelly Abu Bakar; fadzelly@uthm.edu.my

Received 16 March 2015; Revised 31 May 2015; Accepted 1 June 2015

Academic Editor: Kodappully S. Siveen

Copyright (C) 2015 Mohd Fadzelly Abu Bakar et al. This is an open access article distributed under the Creative Commons Attribution License, which permits unrestricted use, distribution, and reproduction in any medium, provided the original work is properly cited.

\begin{abstract}
Garcinia dulcis or locally known in Malaysia as "mundu" belongs to the family of Clusiaceae. The study was conducted to investigate the anticancer potential of different parts of G. dulcis fruit extracts and their possible mechanism of action in HepG2 liver cancer cell line. MTT assay showed that the peel, flesh, and seed extracts of G. dulcis induced cytotoxicity in HepG2 cell line with $\mathrm{IC}_{50}$ values of $46.33 \pm 4.51,38.33 \pm 3.51$, and $7.5 \pm 2.52 \mu \mathrm{g} / \mathrm{mL}$, respectively. The flesh extract of G. dulcis induced cell cycle arrest at sub$\mathrm{G}_{1}$ (apoptosis) phase in a time-dependent manner. Staining with Annexin V-FITC and propidium iodide showed that $41.2 \%$ of the cell population underwent apoptosis after 72 hours of exposure of the HepG2 cell line to G. dulcis flesh extract. Caspase-3 has been shown to be activated which finally leads to the death of HepG2 cell (apoptosis). GC-MS analysis showed that the highest percentage of compound identified in the extract of $G$. dulcis flesh was hydroxymethylfurfural and 3-methyl-2,5-furandione, together with xanthones and flavonoids (based on literature), could synergistically contribute to the observed effects. This finding suggested that the flesh extract of $G$. dulcis has its own potential as cancer chemotherapeutic agent against liver cancer cell.
\end{abstract}

\section{Introduction}

In recent years, studies on the exploitation of natural compounds from fruits for medicinal purposes have received a great attention due to their health-promoting effects. Plants, particularly fruits and vegetables, contain a diverse source of phytochemicals such as phenolics. Daily consumption of fruits and vegetables has been shown to lower the risk of some chronic noncommunicable diseases such as cancer and cardiovascular diseases $[1,2]$. Phenolic compounds have drawn increasing attention since they possess potent antioxidant potential and are abundantly present in fruits and vegetables and have been shown to exhibit anticancer effects. However, it is believed that synergistic or additive biological effects of multiple phytochemicals were involved rather than a single compound or a group of compounds that contribute to cancer treatment and prevention. It is estimated that more than 5000 phytochemicals have been identified and different antiproliferation mechanisms have been reported [3].

The latest world cancer report from International Agency for Research on Cancer (AIRC), a specialized cancer agency of the World Health Organization (WHO), has revealed that the liver cancer is now the second leading cause of death worldwide [4]. Liver cancer is caused by Hepatitis B virus (HBV) which passes from person to person through blood, semen, or other body fluids and can be marked by liver inflammation. The Sun Daily [5] reported that liver cancer in Malaysia (developing country) is on the rise and the fifth most common cancer affecting men where rates are more than twice as high in males as in females. Globally, it is also the 
seventh most commonly diagnosed cancer in adult women where up to a million people die each year from liver cancer. Therefore, early detection is desperately needed to prevent this cancer as this can be prevented by taking Hepatitis B vaccines: World's First Anticancer Vaccines. In 2006, only $27 \%$ of infants worldwide received the first dose of vaccines within 24 hours of birth. As of 2008, a total of 177 countries (91\%) had introduced the HBV vaccine into their national infant immunization schedule as recommended by the WHO [6].

Garcinia dulcis belongs to the family of Clusiaceae (Guttiferae) and is a less common fruit, locally known as "mundu" among Sabahan or Ma-phut in Thailand. The fruit is endemic to Borneo, Java, the Philippines, and Thailand. It is a mediumsized tree, 5 to $20 \mathrm{~m}$ high, often with yellow latex in the fruits and white latex (turns to light brown on exposure to the air) in entire parts of the tree. The leaf is large and leathery with dark green colour. The fruit is spheroid, slightly pointed and turns to yellow-orange when ripe. There are usually 1 to 5 brown seeds embedded in the flesh. The skin of the fruit is thin and soft when ripe while the flesh is pulpy and yellow in colour. The flesh is slightly acidic but pleasant to eat $[7,8]$. However, local people in Thailand used it to enhance the taste in cooking dishes or make pickles because the fruits are too sour to be eaten raw/fresh [9].

Previous literature reported that the leaf and seed of G. dulcis have been used traditionally for the treatment of lymphatitis, parotitis, and goitre whose effects may have been caused by endophytic fungi, known to be present in Garcinia spp. [10]. In Thailand, the stem bark has been used traditionally as anti-inflammatory agent while the fruit juice was used as expectorant. In addition to that, ripe fruit of $G$. dulcis contained at least 22 known compounds and two new compounds (Dulcisflavan and Dulcisxanthone B) [11]. These bioactive compounds played an important role as they might be a great contributor to treat various chronic diseases as reported in previous literature [12]. Therefore, the main objectives of this present study were to determine the anticancer potential of the $80 \%$ aqueous methanol extract of $G$. dulcis towards the proliferation of liver carcinoma (HepG2) cancer cell line in vitro and investigate their possible mechanism of action.

\section{Materials and Methods}

2.1. Plant Materials and Sample Preparation. The fruit of $G$. dulcis was collected from Tenom, Sabah, Malaysian Borneo, in November to December 2012. The plant sample was collected, identified, and deposited at BORNEENSIS Herbarium (BORH), Universiti Malaysia Sabah. The samples were then separated into peel, flesh, and seed. The small-cut pieces were stored at $-80^{\circ} \mathrm{C}$ before being freeze-dried by using freeze dryer. The lyophilized samples were grounded to obtain fine powder. These ground samples were stored in air-tight plastic bag at $-20^{\circ} \mathrm{C}$ for further analysis.

2.2. Sample Extraction. The extraction procedure was conducted according to Ikram et al. [13] with slight modifications. The samples were extracted using $80 \%$ methanol by mixing $0.05 \mathrm{~g}$ of lyophilized fruit powder with $15 \mathrm{~mL}$ solvent. The mixture was placed in a $100 \mathrm{~mL}$ beaker wrapped with aluminium foil and agitated at $200 \mathrm{rpm}$ with the aid of orbital shaker for 2 hours. The mixture was then filtered through filter paper (Whatman number 4) in order to obtain a clear solution. The filtrate was then subjected to vacuum rotary evaporator at $40^{\circ} \mathrm{C}$ to remove methanol residue. The concentrated methanolic extract was freeze-dried to ensure the excess water was removed and crude extracts can be obtained.

2.3. Antiproliferative Assay. The MTT (3-(4,5-dimethylthiazol-2-yl)-2,5-diphenyltetrazolium bromide) assay was conducted based on the method described by Mosmann [14]. The HepG2 cancer cell line was first cultured in RPMI 1640 medium with L-glutamine and supplemented with $10 \%$ of fetal calf serum and $1 \%$ penicillin streptomycin in $75 \mathrm{~cm}^{2}$ flask and incubated at $37^{\circ} \mathrm{C}$ with $5 \% \mathrm{CO}_{2}$ in a humidified atmosphere. The viability of cells was determined by staining with trypan blue. Exponentially growing cells were harvested and counted using haemocytometer. A specific culture medium was used to dilute the cells to a density of $1 \times 10^{6}$ cells $/ \mathrm{mL}$. From this cell suspension, $100 \mu \mathrm{L}$ was pipetted into each well of a 96 -well plate and incubated for $24 \mathrm{~h}$ in a $5 \% \mathrm{CO}_{2}$ incubator at $37^{\circ} \mathrm{C}$. The old media were discarded before the sample extracts were added with the highest concentration of $100 \mu \mathrm{g} / \mathrm{mL}$ and make up the final volume of $100 \mu \mathrm{L}$ in each well. The plate was then incubated in $5 \% \mathrm{CO}_{2}$ incubator at $37^{\circ} \mathrm{C}$ for $72 \mathrm{~h}$. Then, $20 \mu \mathrm{L}$ of MTT reagent (3- $(4,5-$ dimethylthiazol-2-yl)-2,5-diphenyltetrazolium bromide) was added to each well and left in incubator for $4 \mathrm{~h}$. Subsequently, $100 \mu \mathrm{L}$ of solubilization solution (DMSO) was added to each well and reading was taken at wavelength of $570 \mathrm{~nm}$ using ELISA reader. The cytotoxicity percentage was determined using the following formula:

$$
\% \text { cytotoxicity }=\frac{\text { optical density of sample }}{\text { optical density of control }} \times 100 \text {. }
$$

The final results were expressed as inhibition concentration $\left(\mathrm{IC}_{50}\right)$, the concentration of sample able to inhibit cell proliferation by $50 \%$ that was calculated graphically for each cell proliferation curve.

2.4. Cell Cycle Analysis. Cell cycle analysis was conducted according to Abu-Bakar et al. [15]. Cells at density of $1 \times 10^{6}$ cells $/ \mathrm{mL}$ were incubated with the extracts at $\mathrm{IC}_{50}$ value for 24 , 48 , and $72 \mathrm{~h}$. All adhering and floating cells were harvested and transferred into sterile centrifuge tube and centrifuged at $1200 \mathrm{rpm}$ for $10 \mathrm{~min}\left(4^{\circ} \mathrm{C}\right)$. The pellets were then washed with cold phosphate buffered saline (PBS) (10 mM sodium phosphate $\mathrm{pH} 7.2,150 \mathrm{mM}$ sodium chloride) and resuspended in $0.5 \mathrm{~mL}$ of cold PBS. Then, $5 \mathrm{~mL}$ of ice-cold $70 \%$ ethanol was added to the cell suspension and incubated at $-20^{\circ} \mathrm{C}$ for 2 hours. Then, the cells were washed twice with cold PBS and centrifuged again at $1200 \mathrm{rpm}$ for $10 \mathrm{~min}\left(4^{\circ} \mathrm{C}\right)$. After that, $500 \mu \mathrm{L}$ of propidium iodide/RNAse $(10 \mu \mathrm{g} / \mathrm{mL}$ propidium iodide containing $1 \mathrm{mg} / \mathrm{mL}$ RNAse) solution was added to the cells and incubated in the dark for $30 \mathrm{~min}$ at 
room temperature before being analysed by flow cytometer within 3 hours of staining.

2.5. Discrimination of Early and Late Apoptosis. The procedure was conducted according to methodology provided in Annexin V-FITC Apoptosis Detection Kit (catalog number APOAF, Sigma, USA). Cells at density of $1 \times 10^{6}$ cells $/ \mathrm{mL}$ were incubated with the extracts at $\mathrm{IC}_{50}$ value for 24,48 , and $72 \mathrm{~h}$. All adhering and floating cells were harvested and washed twice with PBS before being transferred into sterile centrifuge tube. The cell pellet was then suspended in binding buffer (100 mM HEPES/NaOH, pH 7.5 containing $1.4 \mathrm{M} \mathrm{NaCl}$ and $25 \mathrm{mM} \mathrm{CaCl}_{2}$ ) at a concentration of $\sim 1 \times 10^{6}$ cells per $\mathrm{mL}$. A sample $(500 \mu \mathrm{L})$ of this cell suspension was transferred to a $5 \mathrm{~mL}$ falcon tube, to which $5 \mu \mathrm{L}$ of Annexin V-FITC conjugate and $10 \mu \mathrm{L}$ of propidium iodide were added. The cells were incubated in the dark for 10 minutes at room temperature. The fluorescence of the cells was determined by flow cytometry.

2.6. Assay of Caspase Activity. Caspase-3 Colorimetric Assay (catalog number BF3100, R\&D Systems) was used to determine the activity of caspase-3. Cells $\left(\sim 3 \times 10^{6}\right.$ cells) (treated and untreated) were collected and transferred into sterile centrifuge tube. The cells were centrifuged at $500 \mathrm{rpm}$ for $5 \mathrm{~min}\left(25^{\circ} \mathrm{C}\right)$. Supernatant was discarded and $25 \mu \mathrm{L}$ of cold lysis buffer was added per $1 \times 10^{6}$ cells. The cell lysates were incubated on ice for $10 \mathrm{~min}$. Samples $(50 \mu \mathrm{L})$ of the lysate (supernatant) were aliquoted into 96-well microplate and $50 \mu \mathrm{L}$ of $2 \mathrm{X}$ reaction buffer 3 followed by $0.5 \mu \mathrm{L}$ of $10 \mathrm{mM}$ DTT was added to sample wells. Then, $5 \mu \mathrm{L}$ of caspase3 colorimetric substrate (DEVD-pNA) was added to each reaction well and incubated at $37^{\circ} \mathrm{C}$ for $2 \mathrm{~h}$. Absorbance value was read at $405 \mathrm{~nm}$ using ELISA reader.

2.7. Gas Chromatography-Mass Spectroscopy (GC-MS). The methanolic crude extract of flesh of $G$. dulcis was analysed by gas chromatography equipped with mass spectrometry (GC-MS-2010 Plus-Shimadzu). The column temperature was set to $50^{\circ} \mathrm{C}$ for $4 \mathrm{~min}$, then increased to $320^{\circ} \mathrm{C}$ at the rate of $7^{\circ} \mathrm{C} / \mathrm{min}$, and then held for $20 \mathrm{~min}$. The injector temperature was set at $280^{\circ} \mathrm{C}$ (split mode with the ratio being adjusted to $20: 1$, injection volume $=0.1 \mu \mathrm{L}$ ). The flow rate of the helium carrier gas was set to $1 \mathrm{~mL} / \mathrm{min}$ with total run time of $60 \mathrm{~min}$. Mass spectra were obtained from the range $\mathrm{m} / z 40$ to 700 and the electron ionization was obtained at $70 \mathrm{eV}$. The chromatograms of the sample were identified by comparing their mass spectra with the library data and the GC retention time against known standards (NIST 11 Library and Wiley Library).

2.8. Statistical Analysis. Data were analysed using SPSS software version 17.0 and reported as mean \pm standard deviation. Analysis of variance (ANOVA) with Tukey test and independent sample $t$-test were conducted to identify the significant difference $(P<0.05)$. All the analysis was carried out in triplicate in three independent experiments.
TABLE 1: $\mathrm{IC}_{50}$ value of samples tested against HepG2 cancer line by using MTT.

\begin{tabular}{lc}
\hline Parts & $\mathrm{IC}_{50}$ value $($ mean $\pm \mathrm{SD})$ \\
\hline Peel & $46.33 \pm 4.51$ \\
Flesh & $38.33 \pm 3.51$ \\
Seed & $7.5 \pm 2.52$ \\
Doxorubicin & $2.0 \pm 0.87$ \\
\hline
\end{tabular}

SD: standard deviation; $n=3$.

\section{Results and Discussion}

3.1. Anticancer Potential of G. dulcis Extract on HepG2 Cancer Cell Line. MTT assay is a commonly used method to investigate the cytotoxicity of natural products. This assay is based on the ability of mitochondrial dehydrogenase enzymes from viable cells to cleave the tetrazolium rings of the pale yellow MTT and form dark blue formazan crystals which is largely impermeable to cell membranes, resulting in its accumulation within healthy cells. Thus, the absorbance of the solubilized formazan crystal is proportional to the number of living cells in the system [14].

The incubation of G. dulcis peel, flesh, and seed extract with HepG2 cancer cell line induced cytotoxicity with $\mathrm{IC}_{50}$ values of $46.33 \pm 4.51,38.33 \pm 3.51$, and $7.5 \pm 2.52 \mu \mathrm{g} / \mathrm{mL}$, respectively (Table 1 ). Doxorubicin was used as positive control. The seed extract showed the lowest $\mathrm{IC}_{50}$ value, followed by flesh and peel. The lower the $\mathrm{IC}_{50}$ value, the more effective the anticancer potential of the pure compound or crude extract. Some edible fruit extracts have been previously reported to possess anticancer properties such as cranberry, lemon, apple, strawberry, red grape, banana, and grapefruit that showed potent antiproliferative activity towards HepG2 cell line [16], rowanberry, raspberry, lingonberry, cloudberry, arctic bramble, and strawberry towards HeLa (human cervical cancer) [17].

The inhibition of liver cancer cell lines can be partially explained by the presence of phenolic phytochemicals such as anthocyanins, phenolic acids, carotenoids, and flavonoids as well as xanthone compound that is mainly distributed in Garcinia species. According to Yang et al. [18], specific phytochemicals might act additively, synergistically, and/or antagonistically with other compounds to display antiproliferative activity. Previous study reported that high antioxidant level did not necessarily reflect the high anticancer effect of the plant extract and might be due to synergistic effect of the crude extract itself [19].

In addition to that, Mangostin (a type of xanthone compound) is also found in ripe fruit of $G$. dulcis where the exact compound can also be found in the pericarp of $G$. mangostana especially $\alpha$-mangostin and $\gamma$-mangostin. Consumption of mangosteen pericarp extract (81\% $\alpha$-mangostin and $16 \%$ of $\gamma$-mangostin) in ratio of $0.25 \%$ and $0.5 \%$ extract to food dosage in daily diet has been reported to inhibit tumor growth in HCT116 (human colorectal carcinoma) and reduce blood vessels in tumor towards Athymic NCr nu/nu mice [20]. Previous literature reported the occurrence of at least 24 compounds that have been identified in $G$. dulcis 


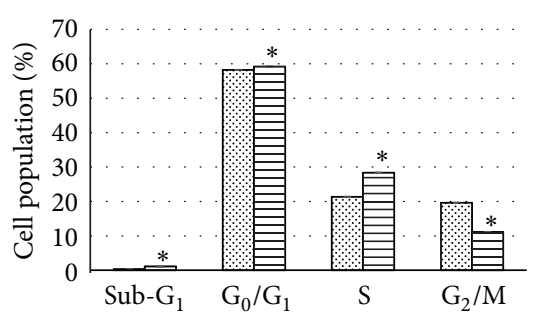

Apoptosis (sub- $\mathrm{G}_{1}$ ) and cell cycle distribution

๑ Control

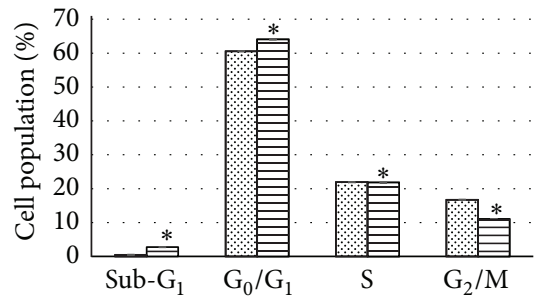

Apoptosis (sub- $\mathrm{G}_{1}$ ) and cell cycle distribution
日 $48 \mathrm{~h}$

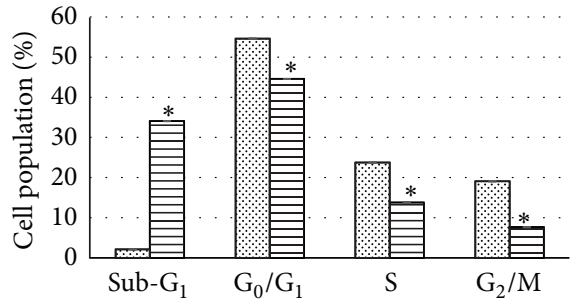

Apoptosis (sub- $\mathrm{G}_{1}$ ) and cell cycle distribution
曰 $72 \mathrm{~h}$

(c) (a)

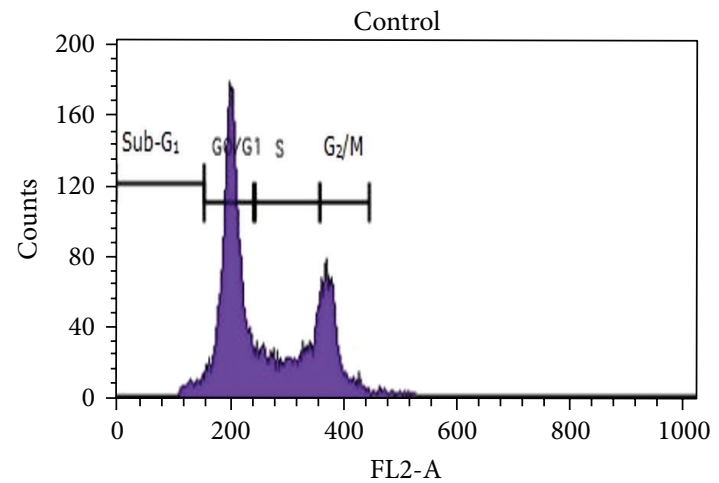

(d)

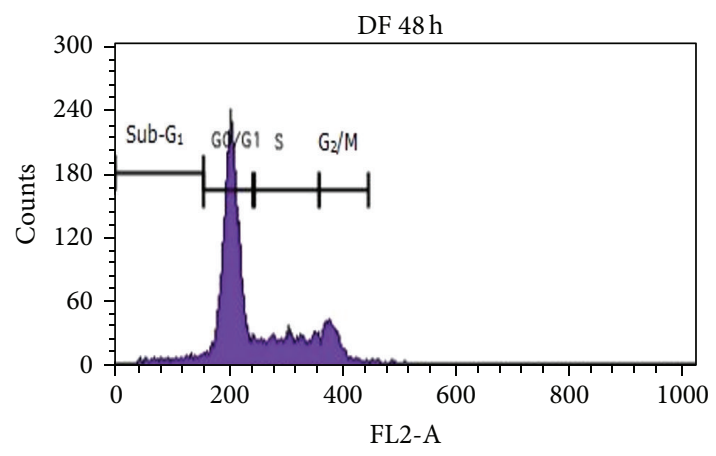

(f)

(b)

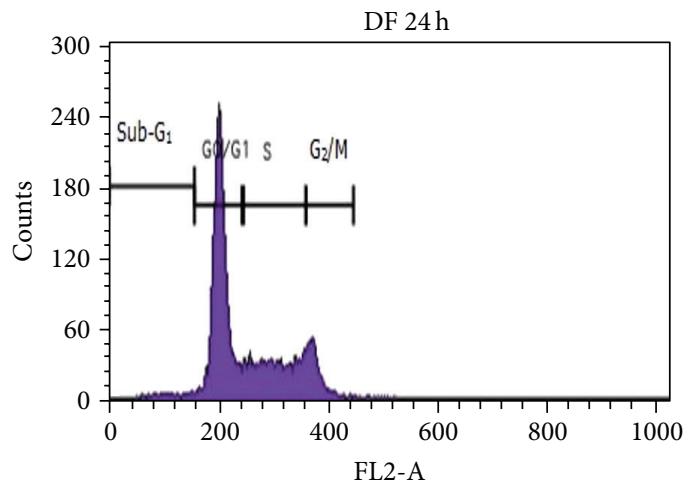

(e)

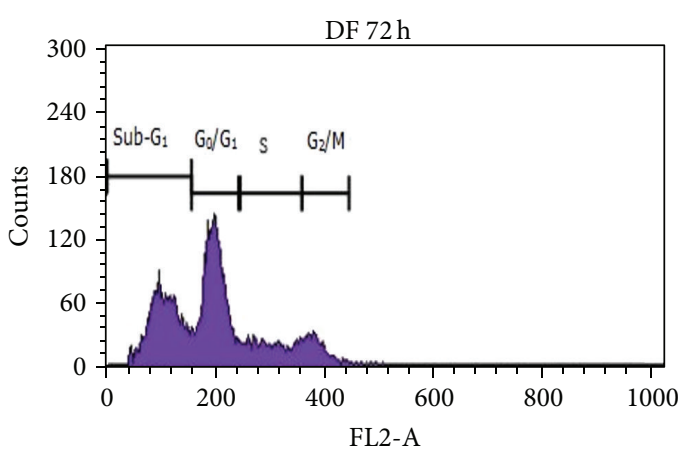

(g)

Figure 1: Cell cycle analysis of HepG2 cancer cell treated with the methanolic flesh extract of G. dulcis at $\mathrm{IC}_{50}$ value. The distribution of cells undergoing apoptosis in various phases of the cell cycle was determined at 24 hours (a), 48 hours (b), and 72 hours (c) in comparison to the respective control. The values are presented as mean \pm standard deviation, where $*$ indicated significant difference relative to control $(P<0.05)$. The representative flow cytometric scans of untreated HepG2 cells and those treated with methanolic flesh extract of $G$. dulcis for 24,48 , and 72 hours are presented in Figures (d) to (g), respectively.

such as Dulcisflavan, Dulcisxanthone B, (-) epicatechin [11], and kaempferol (kaempferol 3,7-di- $O$ - $\alpha$-rhamnopyranoside) [21]. Epicatechin and kaempferol were two flavonoid compounds that belong to flavanols and flavonols, respectively. Kaempferol is known to possess antioxidant and anticancer activity which inhibit cell proliferation of MDA-MB-453 (human breast carcinoma) [22]. All these compounds might act synergistically to inhibit the proliferation of studied cancer cell lines.

3.2. Cell Cycle Distribution on the Flesh of G. dulcis. Due to the fact that only the flesh part of the fruit can be consumed, and also the seed extract induced cytotoxicity in normal mouse fibroblast cell line (data not shown), further experiment on cell cycle distribution and apoptosis-inducing effect of $G$. dulcis only proceeded with the flesh crude extract of $G$. dulcis using the $\mathrm{IC}_{50}$ value of $38 \mu \mathrm{g} / \mathrm{mL}$. Apoptosis and cell cycle arrest in HepG2 cancer cell were studied after exposure to G. dulcis flesh extract at $\mathrm{IC}_{50}$ concentration for 24,48 , and 72 hours (Figure 1). Flow cytometric analysis (using RNAse and propidium iodide) was conducted to measure the DNA content of HepG2 cancer cell which allows us to identify whether the growth inhibitory effect of the fruit extract was caused by specific perturbation of cell cycle-related events. 
The cell cycle analysis demonstrated that the flesh of G. dulcis caused an accumulation of cells in the $G_{0} / G_{1}$ phase. This causes the inhibition transition of cells towards $S$ phase and allowed the increase in the proportion of cells in sub- $\mathrm{G}_{1}$ phase. An obvious accumulation of cells in sub$\mathrm{G}_{1}$ phase can be observed from $2 \%$ in control to $34 \%$ after 72 hours. The increase in sub- $\mathrm{G}_{1}$ phase was a reflection of apoptosis induction. Gradual decrease in $G_{0} / G_{1}$ phase, $S$ phase, and $G_{2} / M$ phase can be observed from $24 \mathrm{~h}$ to 72 hours as compared to control. This condition might be due to the inhibition of DNA replication affected by the inability of the cells to replicate damaged DNA caused by the sample extracts, condensation of chromatin, and nuclear fragmentation [23]. The treatment of SK-MEL-28 (human melanoma) cells with $\alpha$-mangostin significantly increased the sub- $G_{1}$ peak with a concomitant decrease in $G_{1}$ phase, indicating induction of apoptosis [24].

3.3. Early and Late Apoptosis. Apoptosis is a physiological process of killing cells and is an important process to eliminate tumours. The apoptosis process can be characterized by membrane blebbing (without loss of cell integrity), shrinkage of cells and nuclear volume, chromatin condensation, DNA fragmentation, and formation of membrane-bound vesicles (apoptotic bodies) which can be triggered by multiple independent pathways, from within or outside the cell [25].

The Annexin V-FITC Apoptosis Detection kit is the combination of fluorescein isothiocyanate (FITC) and annexin V with propidium iodide to distinguish living cells in early and late apoptosis. The annexin is a group of homologous proteins which bind phospholipids in the presence of calcium. During early apoptosis, phosphatidylserine which is usually located in the inner membrane of cells is transported into the outer portion of the membrane which can be detected by its strong affinity for Annexin V-FITC whereas the dead cells can be detected by the binding of propidium iodide to the cellular DNA in cell [15].

The result showed that there was significant reduction in the proportion of cells in the viable cell group when treated with methanolic flesh extract of G. dulcis (Figure 2). These were concomitant with an increase in the proportion of cells in early and late apoptosis for 24, 48, and 72 hours of treatment when compared to control. The total values of apoptosis increased up to $29.8 \%, 34.0 \%$, and $60.9 \%$, respectively. At 24 hours, the values of viable cell started to decline by $69.8 \%$ as compared to control, with significant increase in early and late apoptosis with the values of $16.7 \%$ and $13.1 \%$. The same trend of reduction in proportion of viable cells and increase of early and late apoptosis were observed for 48 hours. At the end of 72 hours, the total apoptosis increased up to $60.9 \%$ which comprise of early apoptosis (19.7\%) and late apoptosis (41.2\%). Some of the cells induce cell death through necrosis. Necrosis is always considered to be almost "accidental death" that may cause death of the cell at random and uncontrollably. The morphological changes of the cell undergoing apoptosis were shown in Figure 3. The induction of apoptosis was confirmed through activation of caspase.
3.4. Caspase Activity. Caspase- 3 is the most prevalent caspase within cells and responsible for most of apoptotic effects and upon activation, it was able to induce Poly ADP Ribose Polymerase (PARP) cleavage and DNA break and finally leads to apoptosis. The exposure to the flesh of G. dulcis towards HepG2 cancer cell line led to the activation of caspase-3 (Figure 4). This activation confirms that one of the initiator caspases (caspase-2, caspase-8, and caspase-9) was first activated which eventually could activate the executioner caspase (caspase-3, caspase-6, and caspase-7) which in this case was caspase- 3 and thus led to the induction of apoptosis [26]. Caspase-3 was responsible for DNA fragmentation and morphological changes associated with apoptosis whereas caspase- 2 and caspase- 9 were early biomarkers of apoptosis which act as downstream targets of cytochrome $\mathrm{c}$ release from mitochondria which will then activate caspase-3 [27]. This finding was in agreement with previous study [28] where $\alpha$-mangostin was able to suppress cell viability and colony formation which caused cell cycle arrest upon activation of caspase-3 towards PC3 and 22Rv1 (human prostate) cancer cell line. Induction of apoptosis can be observed in COLO205 (human colorectal adenocarcinoma) when exposed to $48 \mathrm{mg}$ of $\alpha$-mangostin and $6.40 \mathrm{mg}$ of $\gamma$-mangostin per gram extract where the apoptosis induction happened at caspase- 3 and caspase- 8 pathway [29].

3.5. Gas Chromatography-Mass Spectroscopy (GC-MS). Methanolic crude extract of flesh of $G$. dulcis was subjected to GC-MS analysis. GC-MS analysis is a widely used method that combines the features of gas chromatography and mass spectrometry purposely to identify compounds in a sample (Figure 5). The identification and characterization of chemical compounds of G. dulcis extracted in $80 \%$ aqueous methanol are shown in Table 2. The highest percentage of compound identified in the crude extract of G. dulcis was hydroxymethylfurfural or 5-hydroxymethylfurfural (HMF).

HMF is an organic compound, absent naturally in food but generated in sugar-containing food during heattreatments like drying or cooking. This compound was commonly found in bakery products, malt, fruit juices, and coffee, with extremely high concentration in some food items such as dried fruits, caramel, and vinegar [30]. HMF was used as marker of quality in processed fruits, coffee, honey, and milk as well as monitoring the heating processes applied to cereal products such as pasta drying, bread baking, bread slices toasting, and extrusion of baby cereals and breakfast cereals [31]. HMF might occur naturally in the fruit or be generated during high temperature processes such as drying or during GC-MS analysis.

Previous study reported that the HMF compound showed cytoprotective effect by protecting LO2 (normal liver cell line) cell against cytotoxicity induced by hydrogen peroxide $\left(\mathrm{H}_{2} \mathrm{O}_{2}\right)$. Hydrogen peroxide is a major precursor of highly reactive free radicals and it has been reported to decrease the viability of cell and induce apoptosis in many cells such as cardiomyocytes, chondrocytes, tendon fibroblasts, 


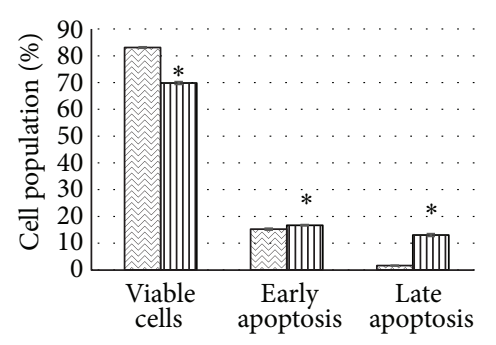

圂 Control

미 $24 \mathrm{~h}$

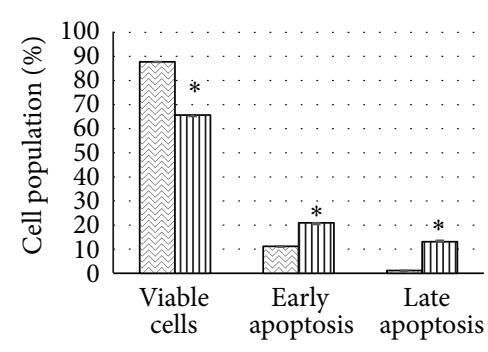

图 Control

四 $48 \mathrm{~h}$

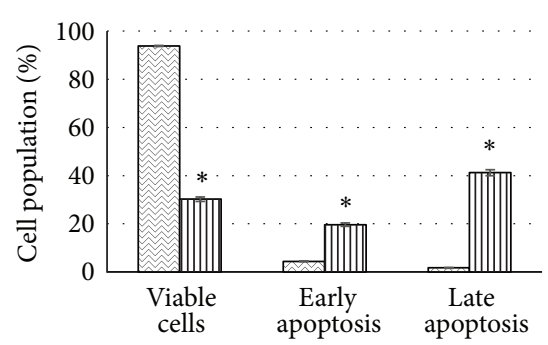

图 Control

四 $72 \mathrm{~h}$

(a)

(b)

(c)

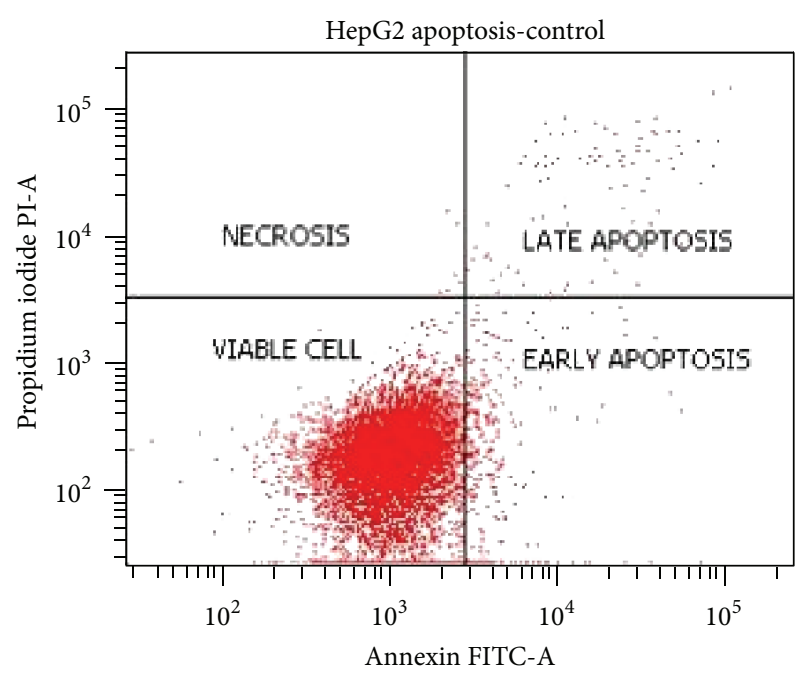

(d)

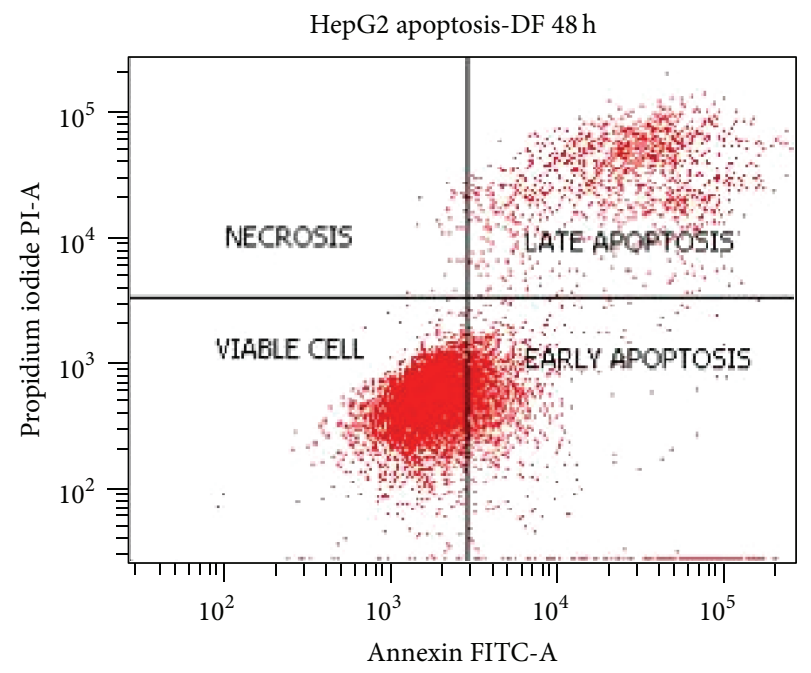

(f)

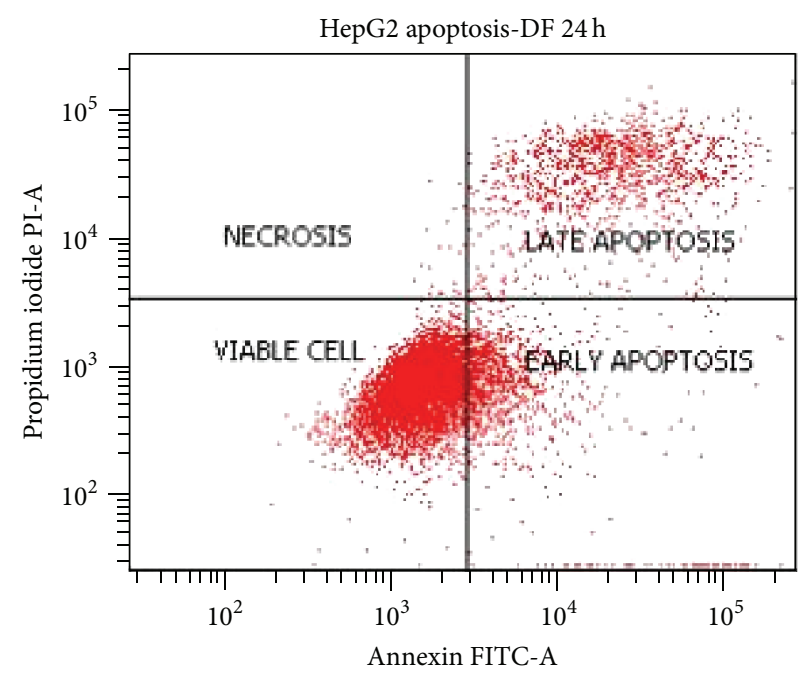

(e)

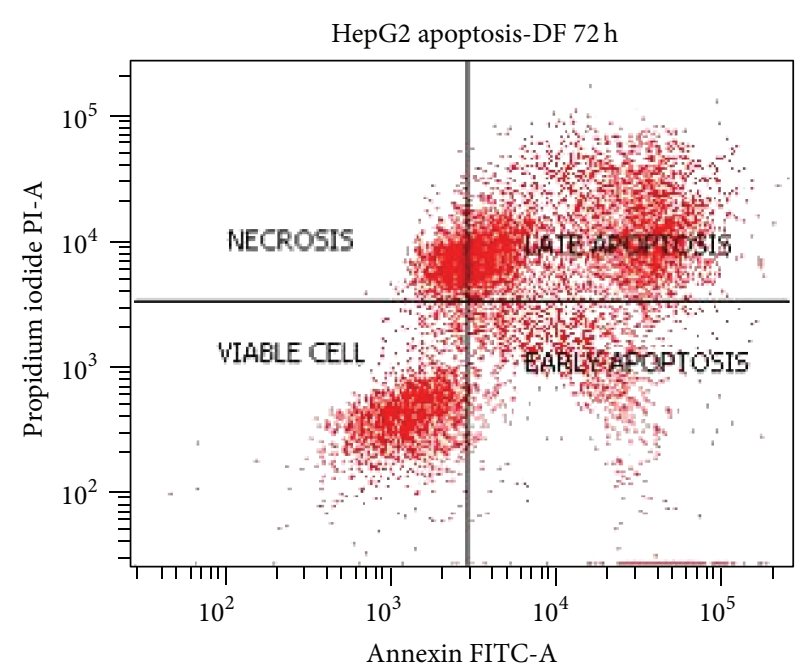

(g)

FIgure 2: Apoptosis study upon treatment of the methanolic flesh extract of G. dulcis at $\mathrm{IC}_{50}$ value. The distribution of cells undergoing early and late apoptosis together with viable cells was determined at 24 hours (a), 48 hours (b), and 72 hours (c) in comparison to respective control, using Annexin V-FITC and propidium iodide flow cytometric analysis. The values are presented as mean \pm standard deviation, where * indicated significant difference relative to control $(P<0.05)$. The representative flow cytometric scans of untreated HepG2 cells and those treated with methanolic flesh extract of G. dulcis for 24, 48, and 72 hours are presented in Figures (d) to (g), respectively. 


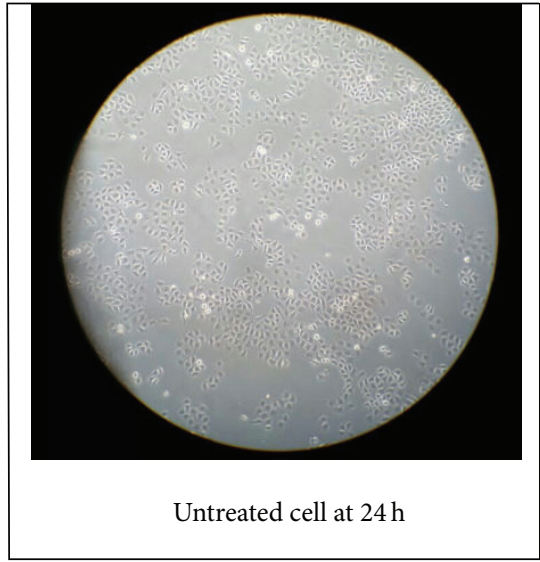

(a)

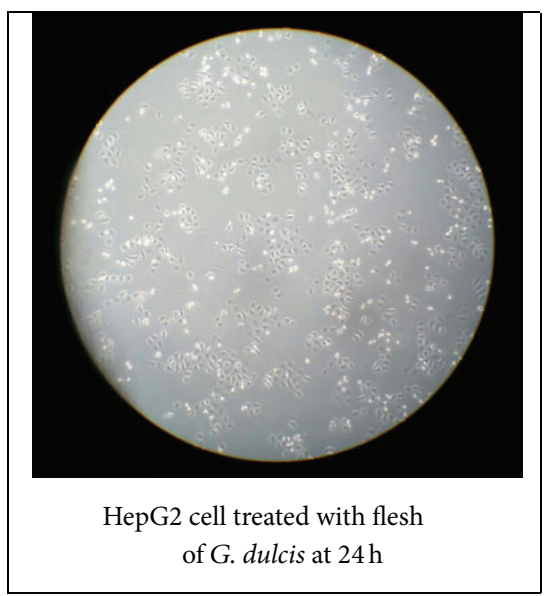

(d)

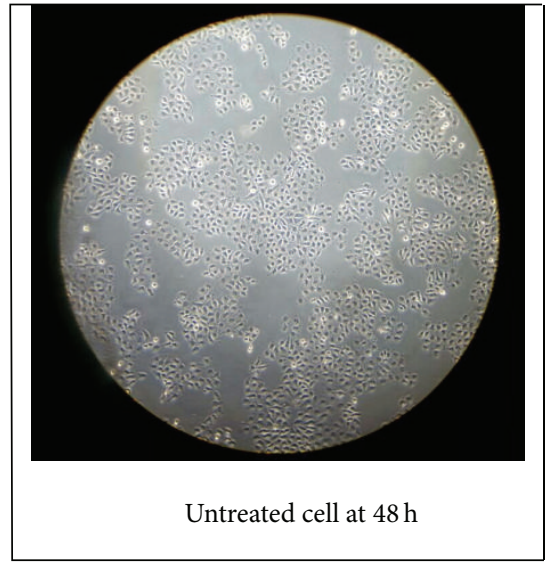

(b)

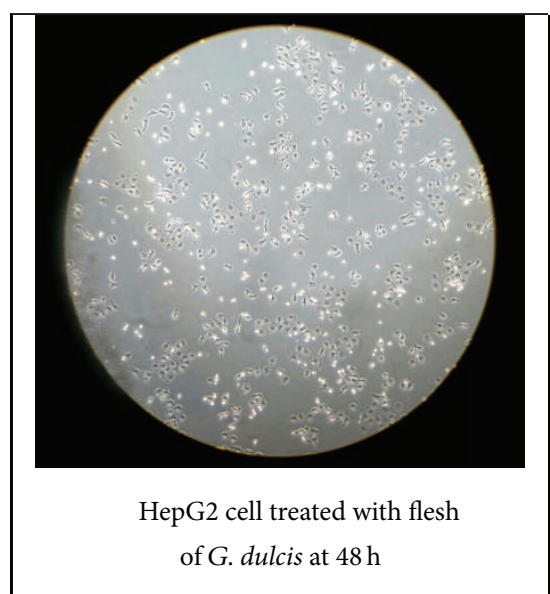

(e)

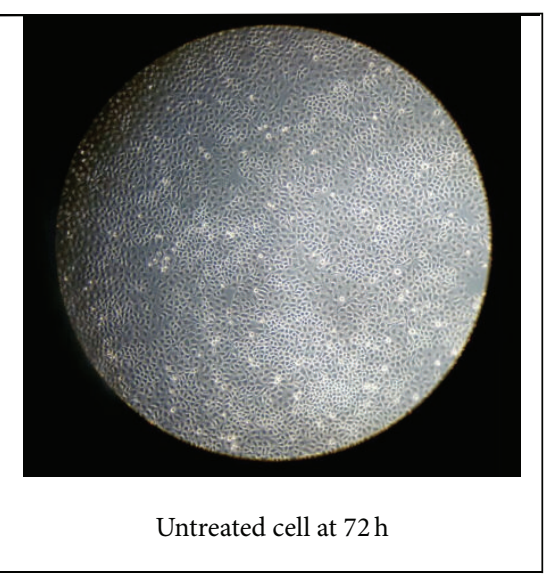

(c)

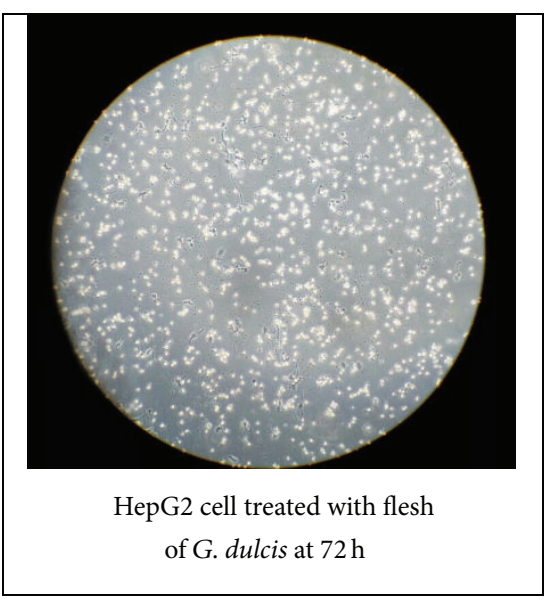

(f)

Figure 3: Morphological changes of HepG2 cancer cell line upon treatment with the flesh of G. dulcis at (d) $24 \mathrm{~h}$, (e) $48 \mathrm{~h}$, and (f) $72 \mathrm{~h}$ compared to untreated cell (a), (b), and (c).

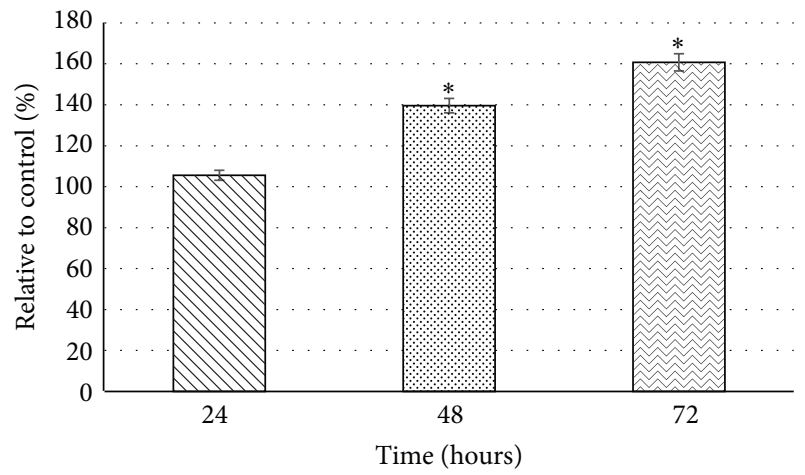

Figure 4: Activation of caspase in HepG2 cancer cell after incubation with methanolic flesh extract of $G$. dulcis at $\mathrm{IC}_{50}$ value for 24,48 , and 72 hours. The values are presented as mean \pm standard deviation, where $*$ indicated significant difference relative to control $(P<0.05)$.

hepatocytes, and human umbilical vein endothelial cell. The compound significantly inhibits the effect of cell apoptosis in a dose-dependent manner after incubation of the cell with $1 \mu \mathrm{g} / \mathrm{mL}$ HMF for 24 hours and thus decreased caspase- 3 activity as well as nitric oxide level [32]. HMF which is also present in roasted coffee residue suppressed cytotoxicity in mouse embryonic fibroblast cell which is induced by hydrogen peroxide [33]. Liu et al. [34] also reported that HMF increases enzyme activities such as superoxide dismutase (SOD) and glutathione peroxidase $(\mathrm{GPx})$ as well as potential therapeutic agent for the treatment of Alzheimer's disease.

In comparison to previous study by Haroun et al. [35], three out of 10 compounds identified in the pomegranate peels extract were also found in methanolic crude extract of flesh of $G$. dulcis, namely, HMF, n-hexadecanoic acid, and octadecanoic acid. These compounds were believed to contribute to antimicrobial effects. Previous research revealed that most of predominate compounds identified in crude extract through GC-MS analysis are biologically active molecules and considered to be part of plant defence system [36]. Hence, it is possible that these compounds present in methanolic crude extract of flesh of $G$. dulcis contributed to the antioxidant and anticancer properties. 


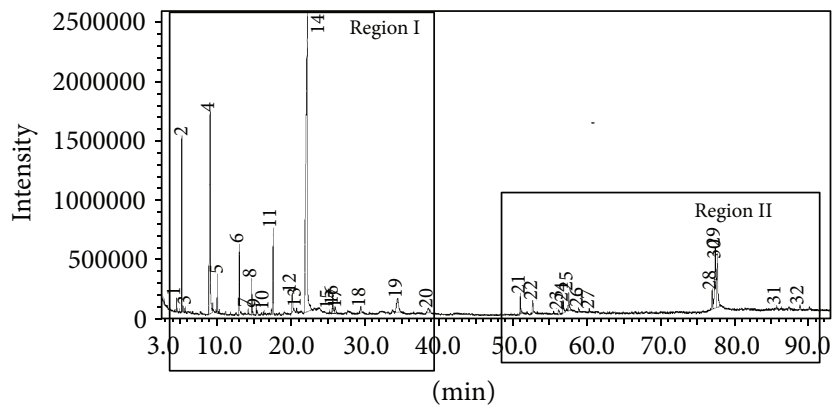

(a) Overall GC-MS analysis

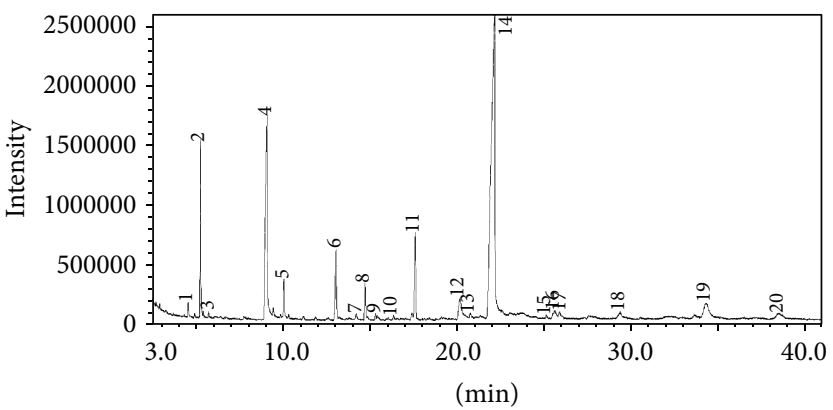

(b) Enlarged from Region I

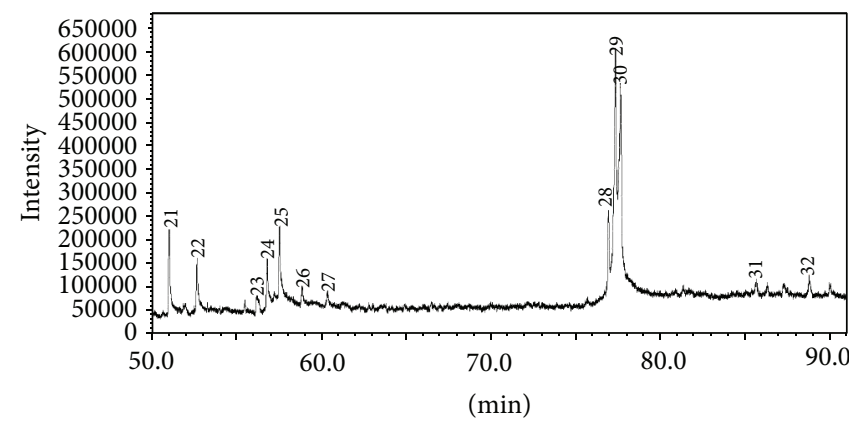

(c) Enlarged from Region II

FIGURE 5: Chemical compounds of methanolic crude extract of G. dulcis detected using GC-MS, with relative retention time $\left({ }^{t} R\right)$; (a), (b) enlarged from Region I and (c) enlarged from Region II.

TABLE 2: Secondary metabolites in the G. dulcis flesh extract based on GC-MS analysis.

\begin{tabular}{|c|c|c|c|}
\hline Peak & RT & Compound name & $\%$ \\
\hline 14 & 22.175 & 5-Hydroxymethylfurfural & 39.61 \\
\hline 4 & 9.062 & 2,5-Furandione, 3-methyl- & 26.24 \\
\hline 2 & 5.263 & Furfural & 6.65 \\
\hline 13 & 20.732 & 1-Butanol, 2-methyl-, propanoate (CAS) 2-methylbutyl propionate & 0.54 \\
\hline 12 & 20.130 & Catechol & 4.35 \\
\hline 6 & 13.024 & 2,5-Furandione, dihydro-3-methylene- & 3.53 \\
\hline 11 & 17.579 & 4H-Pyran-4-one, 2,3-dihydro-3,5-dihydroxy-6-methyl- & 3.33 \\
\hline 8 & 14.697 & Furyl hydroxymethyl ketone & 3.09 \\
\hline 19 & 34.318 & D-Allose & 2.68 \\
\hline 5 & 10.047 & 2,4-Dihydroxy-2,5-dimethyl-3(2H)-furan-3-one & 1.20 \\
\hline 20 & 38.486 & 1,6-Anhydro-.alpha.-d-galactofuranose & 1.16 \\
\hline 22 & 52.692 & 5,5'-Oxy-dimethylene-bis(2-furaldehyde) & 0.94 \\
\hline 1 & 4.556 & 1,4-Dioxadiene & 0.59 \\
\hline 7 & 14.198 & 1,3,5-Triazine-2,4,6-triamine & 0.49 \\
\hline 21 & 51.056 & n-Hexadecanoic acid & 0.36 \\
\hline 9 & 15.298 & 1,3,5-Triazine-2,4,6-triamine & 0.33 \\
\hline 25 & 57.555 & Octadecanoic acid & 0.32 \\
\hline 24 & 56.821 & Heptadecene-(8)-carbonic acid-(1) & 0.27 \\
\hline 3 & 5.713 & 2-Furanmethanol & 0.14 \\
\hline
\end{tabular}

RT: retention time. 


\section{Conclusion}

In conclusion, the methanolic flesh extract of $G$. dulcis has demonstrated promising anticancer properties against liver cancer. Increasing awareness, promotion, and utilization of this fruit for public benefits are highly encouraged. Proteomic, genomic, in vivo, and human clinical studies are needed to determine the efficacy of the fruit extract to serve as natural cytotoxic agent in cancer patient.

\section{Conflict of Interests}

The authors declare that there is no conflict of interests.

\section{Acknowledgments}

The authors would like to acknowledge the Ministry of Higher Education of Malaysia (MOHE) for financial assistance under the Exploratory Research Grant Scheme, ERGS (Project no. ERGS0028-STWN-1/2012), the Institute for Tropical Biology and Conservation, Seaweed Research Laboratory, Faculty of Science and Natural Resources, Universiti Malaysia Sabah, Malaysia, Department of Nutrition and Dietetic, Universiti Putra Malaysia, Malaysia, and Sabah Department of Agriculture, Kota Kinabalu, Sabah, for the permission of using the facilities and technical assistance.

\section{References}

[1] M. S. Rabeta, S. Chan, G. D. Neda, K. L. Lam, and M. T. Ong, "Anticancer effect of underutilized fruits," International Food Research Journal, vol. 20, no. 2, pp. 551-556, 2013.

[2] M. F. Abu Bakar, M. Mohamed, A. Rahmat, and J. Fry, "Phytochemicals and antioxidant activity of different parts of bambangan (Mangifera pajang) and tarap (Artocarpus odoratissimus)," Food Chemistry, vol. 113, no. 2, pp. 479-483, 2009.

[3] N. Jia, Y. L. Xiong, B. Kong, Q. Liu, and X. Xia, "Radical scavenging activity of black currant (Ribes nigrum L.) extract and its inhibitory effect on gastric cancer cell proliferation via induction of apoptosis," Journal of Functional Foods, vol. 4, no. 1, pp. 382-390, 2012.

[4] World Cancer Report 2014, http://livercancerconnect.org.

[5] A. F. Cruez, "Liver cancer on the rise," The Sun Daily, 2014, http://www.thesundaily.my/news/1150045.

[6] A. Jemal, F. Bray, M. M. Center, J. Ferlay, E. Ward, and D. Forman, "Global cancer statistics," CA-Cancer Journal for Clinicians, vol. 61, no. 2, pp. 69-90, 2011.

[7] M. Osman and A. R. Milan, Fruits of the Future 9: Mangosteen Garcinia mangostana L., Southampton Centre for Underutilised Crops, Southampton, UK, 2006.

[8] W. W. W. Wong, T. C. Chong, J. Tananak, H. Ramba, and N. Kalitu, Fruits of Sabah, vol. 1, Department of Agriculture Sabah, Sabah, Malaysia, 2007.

[9] C. Yapwattanaphun, S. Subhadrabandhu, A. Sugiura, K. Yonemori, and N. Utsunomiya, "Utilization of some Garcinia species in Thailand," in Proceedings of the International Symposium on Tropical \& Subtropical Fruits, pp. 563-570, International Society for Horticultural Science, Cairns, Australia, 2002.
[10] S. Phongpaichit, N. Rungjindamai, V. Rukachaisirikul, and J. Sakayaroj, "Antimicrobial activity in cultures of endophytic fungi isolated from Garcinia species," FEMS Immunology and Medical Microbiology, vol. 48, no. 3, pp. 367-372, 2006.

[11] S. Deachathai, W. Mahabusarakam, S. Phongpaichit, and W. C. Taylor, "Phenolic compounds from the fruit of Garcinia dulcis," Phytochemistry, vol. 66, no. 19, pp. 2368-2375, 2005.

[12] M. Hemshekhar, K. Sunitha, M. S. Santhosh et al., "An overview on genus Garcinia: phytochemical and therapeutical aspects," Phytochemistry Reviews, vol. 10, no. 3, pp. 325-351, 2011.

[13] E. H. K. Ikram, K. H. Eng, A. M. M. Jalil et al., "Antioxidant capacity and total phenolic content of Malaysian underutilized fruits," Journal of Food Composition and Analysis, vol. 22, no. 5, pp. 388-393, 2009.

[14] T. Mosmann, "Rapid colorimetric assay for cellular growth and survival: application to proliferation and cytotoxicity assays," Journal of Immunological Methods, vol. 65, no. 1-2, pp. 55-63, 1983.

[15] M. F. Abu-Bakar, M. Mohamed, A. Rahmat, S. A. Burr, and J. R. Fry, "Cytotoxicity and polyphenol diversity in selected parts of Mangifera pajang and Artocarpus odoratissimus fruits," Nutrition \& Food Science, vol. 40, no. 1, pp. 29-38, 2010.

[16] J. Sun, Y.-F. Chu, X. Wu, and R. H. Liu, "Antioxidant and antiproliferative activities of common fruits," Journal of Agricultural and Food Chemistry, vol. 50, no. 25, pp. 7449-7454, 2002.

[17] G. J. McDougall, H. A. Ross, M. Ikeji, and D. Stewart, "Berry extracts exert different antiproliferative effects against cervical and colon cancer cells grown in vitro," Journal of Agricultural and Food Chemistry, vol. 56, no. 9, pp. 3016-3023, 2008.

[18] J. Yang, R. H. Liu, and L. Halim, "Antioxidant and antiproliferative activities of common edible nut seeds," $L W T$-Food Science and Technology, vol. 42, no. 1, pp. 1-8, 2009.

[19] L. J. Jing, M. F. Abu Bakar, M. Mohamed, and A. Rahmat, "Effects of selected Boesenbergia species on the proliferation of several cancer cell lines," Journal of Pharmacology and Toxicology, vol. 6, no. 3, pp. 272-282, 2011.

[20] A. F. A. Aisha, K. M. Abu-Salah, Z. D. Nassar, M. J. Siddiqui, Z. Ismail, and A. M. S. A. Majid, "Antitumorigenicity of xanthonesrich extract from Garcinia mangostana fruit rinds on HCT 116 human colorectal carcinoma cells," Brazilian Journal of Pharmacognosy, vol. 21, no. 6, pp. 1025-1034, 2011.

[21] W. Mahabusarakam, P. Wiriyachitra, and W. C. Taylor, "Chemical constituents of Garcinia mangostana," Journal of Natural Products, vol. 50, no. 3, pp. 474-478, 1987.

[22] A. E.-M. M. R. Afify, S. A. Fayed, E. A. Shalaby, and H. A. ElShemy, "Syzygium cumini (pomposia) active principles exhibit potent anticancer and antioxidant activities," African Journal of Pharmacy and Pharmacology, vol. 5, no. 7, pp. 948-956, 2011.

[23] J. Li, Y. Cheng, W. Qu et al., "Fisetin, a dietary flavonoid, induces cell cycle arrest and apoptosis through activation of p53 and inhibition of NF-Kappa B pathways in bladder cancer cells," Basic \& Clinical Pharmacology \& Toxicology, vol. 108, no. 2, pp. 84-93, 2011.

[24] J. J. Wang, B. J. S. Sanderson, and W. Zhang, "Cytotoxic effect of xanthones from pericarp of the tropical fruit mangosteen (Garcinia mangostana Linn.) on human melanoma cells," Food and Chemical Toxicology, vol. 49, no. 9, pp. 2385-2391, 2011.

[25] S. H. Kaufmann and W. C. Earnshaw, "Induction of apoptosis by cancer chemotherapy," Experimental Cell Research, vol. 256, no. 1, pp. 42-49, 2000.

[26] J. Cortese, "A wealth of regents exists to probe caspases activities," The Scientist, vol. 15, no. 13, p. 24, 2001. 
[27] S. Gupta, G. E. N. Kass, E. Szegezdi, and B. Joseph, "The mitochondrial death pathway: a promising therapeutic target in diseases," Journal of Cellular and Molecular Medicine, vol. 13, no. 6, pp. 1004-1033, 2009.

[28] J. J. Johnson, S. M. Petiwala, D. N. Syed et al., " $\alpha$-Mangostin, a xanthone from mangosteen fruit, promotes cell cycle arrest in prostate cancer and decreases xenograft tumor growth," Carcinogenesis, vol. 33, no. 2, pp. 413-419, 2012.

[29] R. Watanapokasin, F. Jarinthanan, A. Jerusalmi et al., "Potential of xanthones from tropical fruit mangosteen as anti-cancer agents: caspase-dependent apoptosis induction in vitro and in mice," Applied Biochemistry and Biotechnology, vol. 162, no. 4, pp. 1080-1094, 2010.

[30] M. Murkovic and N. Pichler, "Analysis of 5-hydroxymethylfurfual in coffee, dried fruits and urine," Molecular Nutrition and Food Research, vol. 50, no. 9, pp. 842-846, 2006.

[31] E. Capuano and V. Fogliano, "Acrylamide and 5-hydroxymethylfurfural (HMF): a review on metabolism, toxicity, occurrence in food and mitigation strategies," LWT-Food Science and Technology, vol. 44, no. 4, pp. 793-810, 2011.

[32] X. Ding, M.-Y. Wang, Y.-X. Yao, G.-Y. Li, and B.-C. Cai, "Protective effect of 5-hydroxymethylfurfural derived from processed Fructus corni on human hepatocyte LO2 injured by hydrogen peroxide and its mechanism," Journal of Ethnopharmacology, vol. 128, no. 2, pp. 373-376, 2010.

[33] J.-S. Sung, E.-B. Go, and H.-S. Shin, "Cytoprotective activity of extract of roasted coffee residue on mouse embryonic fibroblasts cells against apoptosis induced by oxidative stress," Food Science and Biotechnology, vol. 21, no. 1, pp. 137-143, 2012.

[34] A. Liu, X. Zhao, H. Li et al., "5-Hydroxymethylfurfural, an antioxidant agent from Alpinia oxyphylla Miq. improves cognitive impairment in $A \beta 1-42$ mouse model of Alzheimer's disease," International Immunopharmacology, vol. 23, no. 2, pp. 719-725, 2014.

[35] B. M. Haroun, A. A. Elghamry, E. H. Abdel-Shakour, S. M. Elmorsy, and Y. H. Zahem, "Determination of bioactive compounds of Punica granatum punicaceae and studying its antimicrobial activities against bacteria isolated from El-Manzala water treatment planet," World Rural Observation, vol. 6, no. 1, pp. 79-86, 2014.

[36] M. A. Hossain, W. A. S. Al-Toubi, A. M. Weli, Q. A. Al-Riyami, and J. N. Al-Sabahi, "Identification and characterization of chemical compounds in different crude extracts from leaves of Omani neem," Journal of Taibah University for Science, vol. 7, no. 4, pp. 181-188, 2013. 

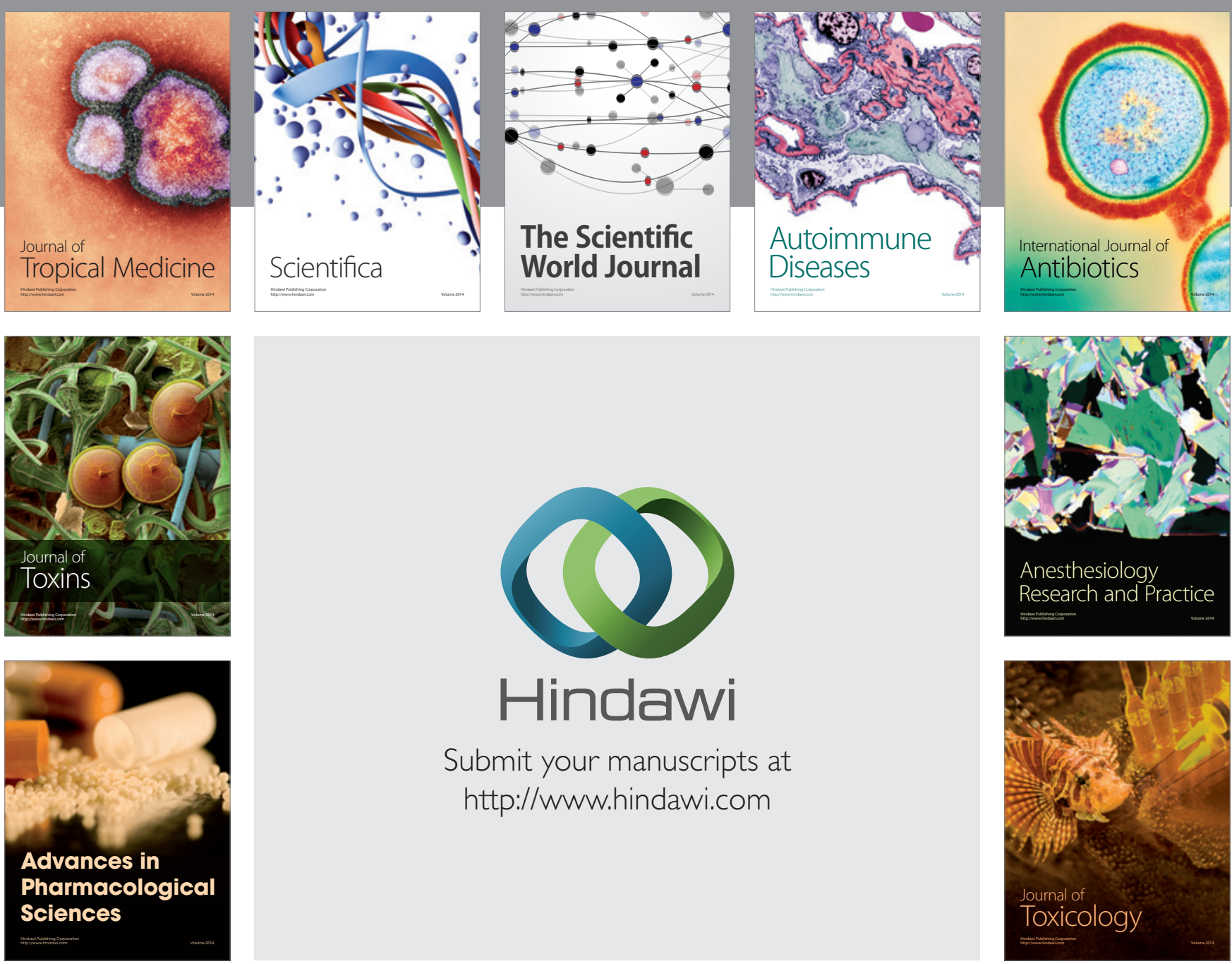

\section{Hindawi}

Submit your manuscripts at

http://www.hindawi.com
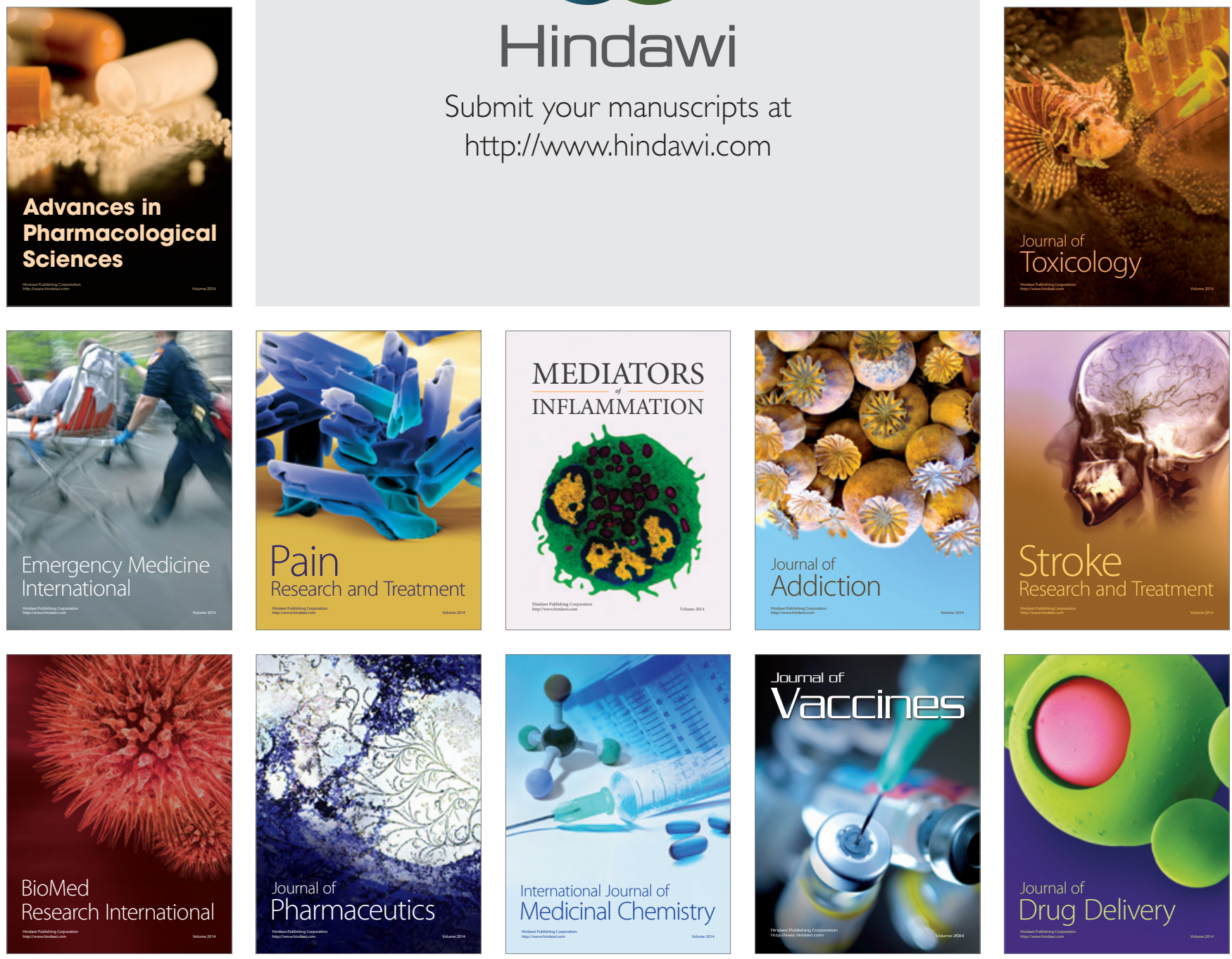